\title{
Tanggung Jawab Ahli Waris dari Penjamin pada Perusahaan yang Pailit Ditinjau dari Hukum Waris Islam
}

\author{
Lenny Nadriana dan Eman Suparman \\ Program Doktor Ilmu Hukum Universitas Padjadjaran Bandung \\ Jln. Banda No. 42, Bandung \\ lennynad@yahoo.co.id.
}

Received: 24 September 2017; Accepted: 29 November 2017; Published: 28 Februari 2018

DOI: 10.20885/iustum.vol24.iss3.art3

\begin{abstract}
This research aimed to discuss these problems. First, how is the obligation of heirs related to the debt of the testator according to Islamic law. Second, how is the liability of the heirs as an insolvent debtor against the individual guarantee agreement made by the testator according to Islamic law. This was a normative legal research, that is a library research making use of secondary data that consist of primary, secondary, and tertiary legal materials. The results showed that, firstly, according to Islamic Inheritance Law, the heirs of the testator who owns individual guarantee agreement have an obligation to repay the debt of the testator as specified in Article 175 paragraph (2) of Compilation of Islamic Law. Secondly, the legal consequence for the heirs of individual guarantee agreement is bankrupt, thus there can be no confiscation of any properties of the heirs to pay off all of their creditor's debts. This means that the heirs' liabilities are limited. The heirs are only liable for paying off the debts using the inheritance from the testator, and not required to cover the unpaid debt that arises because the inheritance is not enough for debt repayment.
\end{abstract}

Keywords: Insolvent Debtors; Heirs; Individual Guarantee; Liability

\section{Abstrak}

Penelitian ini mengajukan permasalahan untuk diteliti sebagai berikut. Pertama, bagaimana kewajiban ahli waris terhadap utang pewaris berdasarkan hukum Islam. Kedua, bagaimana pertanggungjawaban ahli waris sebagai debitor pailit terhadap perjanjian jaminan perorangan yang dibuat pewaris ditinjau dari aspek hukum Islam. Metode Penelitian yang digunakan adalah penelitian hukum normative, yaitu penelitian kepustakaan yang sumbernya menggunakan data sekunder yang terdiri dari bahan hukum primer, sekunder, dan tersier. Hasil penelitian menyimpulkan, pertama, ahli waris dari pewaris pemegang jaminan perorangan jika ditinjau dalam aspek hukum waris Islam, maka ahli waris mempunyai kewajiban untuk membayar utang dari pewarisnya sebagaimana ditentukan dalam Pasal 175 ayat (2) Kompilasi Hukum Islam. Kedua, akibat hukum bagi ahli waris pemegang jaminan perorangan dipailitkan maka tidak dapat dilakukan sitaan umum terhadap segala harta kekayaan milik ahli waris untuk melunasi seluruh utang kreditornya. Artinya, tanggungjawab ahli waris bersifat terbatas. Ahli waris hanya bertanggungjawab melunasi utang sebatas dari harta peninggalan pewaris dan tidak diwajibkan untuk menutupi kekurangan yang timbul karena harta peninggalan tidak cukup bagi pelunasan utang.

Kata-kata Kunci: Debitor Pailit; Ahli Waris; Jaminan Perorangan; Tanggung Jawab 


\section{Pendahuluan}

Hukum Jaminan mengatur mengenai hak jaminan perorangan yang timbul hubungan hukum antara kreditor dengan pihak ketiga yakni sebagai penjamin bagi debitor. Perjanjian jaminan perorangan merupakan hak relatif yaitu hak yang hanya dapat dipertahankan terhadap orang tertentu yang terkait dalam perjanjian. Pihak ketiga bertindak sebagai penjamin dalam pemenuhan kewajiban debitor, berarti perjanjian jaminan perorangan merupakan janji untuk memenuhi kewajiban debitor, apabila debitor ingkar janji. ${ }^{1}$ Dengan kata lain, jaminan perorangan adalah suatu perjanjian antara seorang berpiutang (kreditor) dengan seorang pihak ketiga, yang menjamin dipenuhinya kewajiban-kewajiban debitor. ${ }^{2}$

Penjamin yang telah meninggal dunia namun masih meninggalkan utang maka pada saat itu juga kewajibanya jatuh terhadap ahli warisnya, sehingga statusnya berubah menjadi penjamin menggantikan pewarisnya. Ketentuan tersebut diatur dalam Pasal 1826 Burgerlijk Wetboek atau selanjutnya disebut "BW", adapun bunyinya sebagai berikut: Perikatan-perikatan penanggung beralih kepada para ahli warisnya. Kewajiban utang beralih atau turun kepada ahli waris penanggung apabila penanggung adalah penanggung perseroan yang meninggal dunia pada masa penanggungan. Penanggung yang melepaskan hak istimewanya telah menyatakan diri bertanggung jawab renteng dengan debitor, jika debitor maupun penanggung tidak mampu memenuhi kewajibanya, maka kreditor dapat memohonkan pailit dan menuntut pertanggungjawaban secara tanggung renteng. ${ }^{3}$ Kewajiban ahli waris terhadap perikatan-perikatan penjamin dapat dijadikan debitor utama, kreditor dapat juga mengajukan permohonan pernyataan pailit terhadap ahli waris. Akibat hukum bagi ahli waris yang dinyatakan pailit maka segala harta kekayaanya baik yang ada maupun akan ada dikemudian hari menjadi pelunasan utang bagi para kreditor.

Pengaturan mengenai konsekuensi bagi ahli waris untuk menanggung segala utang pewaris yang diatur di dalam BW berbeda dengan yang diatur dalam

\footnotetext{
${ }^{1}$ Niken Prasetyawati dan Tony Hanoraga, "Jaminan Kebendaan dan Jaminan Perorangan Sebagai Upaya Perlindungan Hukum Bagi Pemilik Piutang”, Jurnal Sosial Humaniora, Vol. 8 No. 1, Juni 2015, hlm. 129.

${ }^{2}$ Hermansyah, Hukum Perbankan Nasional Indonesia, Prenada Media Group, Jakarta, 2014, hlm. 74.

3 Yudha Pradana, "Kedudukan Ahli Waris Penanggung Perseroan Pada Perseroan Terbatas Yang Dipailitkan Secara Bersama-sama”, Diponegoro Law Journal, Vol. 5 No. 3, Juli 2016, hlm. 3.
} 
ketentuan hukum Islam. Bagi WNI yang beragama Islam pengaturan mengenai hukum waris telah diatur dalam Kompilasi Hukum Islam yang selanjutnya disebut KHI. Pengertian ahli waris menurut menurut Pasal 171 huruf (c) KHI yakni: "Ahli waris adalah orang yang pada saat meninggal dunia mempunyai hubungan darah atau hubungan perkawinan dengan pewaris, beragama Islam dan tidak terhalang hukum untuk menjadi ahli waris". Pengertian waris menurut hukum Islam yakni ialah takdir (qadar/ketentuan), dan pada syara' adalah bagian-bagian yang diqadarkan/ditentukan bagi waris. Dengan demikian faraidh adalah khusus mengenai bagian ahli waris yang telah ditentukan besar kecilnya oleh syara' ${ }^{4}$

Setiap pemeluk agama Islam berkewajiban menerima segala kewarisan yang diterimanya dari pewaris, yang juga semata-mata menjalankan perintah Allah sebagaimana tercantum di dalam Al-Quran dan Hadits. Komari mengatakan melaksanakan hukum kewarisan dalam sistem hukum Islam merupakan ibadah muamalah artinya ibadah yang berhubungan dengan sesama manusia yang dilaksanakan semata-mata mendapatkan keridhaan kepada Allah. Dalam ajaran Islam manusia apabila benar-benar mengharapkan keridhoan Allah SWT dalam ibadah harus sesuai dengan ketentuan dan pedoman pada Rasulullah SAW. ${ }^{5}$

Warisan atau harta peninggalan menurut hukum Islam yaitu sejumlah harta benda serta segala hak dari yang meninggal dunia dalam keadaan bersih. Keadaan bersih artinya harta peninggalan yang akan diwarisi oleh para ahli waris adalah sejumlah harta benda setelah dikurangi dengan pembayaran utang-utang pewaris dan pembayaran-pembayaran lain yang diakibatkan oleh wafatnya si peninggal warisan. ${ }^{6}$

Pada praktiknya terlepas pengaturan hukum kepailitan juga masih menerapkan ketentuan hukum BW terhadap kewajiban ahli waris untuk menanggung segala utang penjamin pada perusahaan yang pailit. Salah satu kasus mengenai kewajiban ahli waris dari pewaris pemegang jaminan perorangan yakni dalam kasus kepailitan Putusan Pengadilan Niaga Makasar Nomor: 02/Pdt.Sus.Pailit/2014/PN Niaga Mks (judex facti) juncto Putusan Nomor 19

\footnotetext{
${ }^{4}$ Mohammad Yasir Fauzi, "Legislasi Hukum Kewarisan Indonesia", Jurnal Pengembangan Masyarakat Islam, Vol. 9 No. 2, Agustus 2016, hlm. 55.

${ }^{5}$ Komari, "Dinamisasi dan Elastistas Hukum Kewarisan Islam", Jurnal Hukum dan Peradilan, Vol. 1 No. 3 , Nopember 2012, hlm. 474-475.

${ }^{6}$ Oemar Salim, Dasar-Dasar Hukum Waris di Indonesia, PT Bina Aksara, Jakarta, 2008, hlm. 16.
} 
K/Pdt.Sus-Pailit/2015 (judex juris) Juncto Putusan Mahkamah Agung Nomor 125 Pk/Pdt.Sus-Pailit/2015. Berdasarkan putusan majelis hakim menjatuhkan pailit terhadap ahli waris dari penjamin yang telah meninggal dunia. Ahli waris bertanggung jawab terhadap segala harta yang dimiliki oleh ahli waris baik harta pribadi maupun harta yang diterima dari boedel waris menjadi sitaan umum oleh kurator. Melihat praktik putusan pengadilan tersebut membawa konsekuensi hukum bagi orang yang menundukkan diri pada hukum Islam terhadap kewajiban ahli waris menanggung segala utang pewaris penjamin di dalam kepailitan.

\section{Rumusan Masalah}

Berdasarkan uraian dalam latar belakang tersebut, diambil permasalahan, pertama, bagaimana kewajiban ahli waris terhadap utang pewaris berdasarkan hukum Islam? Kedua, bagaimana pertanggungjawaban ahli waris sebagai debitor pailit terhadap perjanjian jaminan perorangan yang dibuat pewaris ditinjau dari aspek hukum Islam?

\section{Tujuan Penelitian}

Adapun tujuan penelitian ini, pertama, untuk mengetahui kewajiban ahli waris terhadap utang pewaris berdasarkan hukum Islam. Kedua, untuk menganalisis pertanggungjawaban ahli waris sebagai debitor pailit terhadap perjanjian jaminan perorangan yang dibuat pewaris ditinjau dari aspek hukum Islam.

\section{Metode Penelitian}

Metode penelitian yang digunakan dalam penelitian ini adalah metode penelitian hukum normatif, di mana pengolahan dan analisis datanya hanya mengenal data sekunder saja, yang terdiri dari bahan hukum primer, bahan hukum sekunder, dan bahan hukum tersier.

Jenis data dan bahan hukum yang digunakan di dalam penelitian ini menggunakan data sekunder. Data sekunder terdiri dari bahan hukum primer, bahan hukum sekunder, dan bahan hukum tersier. Bahan hukum primer yang digunakan dalam penelitian ini yakni, bahan-bahan yang mengikat berupa Kitab Undang-Undang Hukum Perdata Burgerlijk Wetboekvoor Indonesie (BW), UndangUndang No. 37 Tahun 2004 tentang Kepailitan dan Penundaan Kewajiban 
Pembayaran Utang, Undang-Undang No. 1 Tahun 1974 tentang Perkawinan, Kompilasi Hukum Islam, Putusan Peninjauan Kembali Mahkamah Agung No.125 PK/Pdt. Sus/Pailit/2015, Putusan Kasasi Mahkamah Agung No. 19 K/Pdt.SusPailit/2015, Putusan Kasasi Mahkamah Agung No. 3574 K/Pdt./2000, Putusan Pengadilan Niaga Makassar Pada Pengadilan Negeri Makassar No. 02/ Pailit/2014/PN.Niaga.Mks. Bahan hukum sekunder yaitu bahan yang memberikan penjelasan mengenai bahan hukum primer. Bahan hukum primer berupa publikasi hukum yang tidak berupa dokumen-dokumen resmi, seperti buku-buku hukum kepailitan, hukum jaminan, hukum waris islam, hukum waris barat/BW, hukum perjanjian. Bahan hukum tersier merupakan bahan yang memberikan informasi, petunjuk maupun penjelasan terhadap bahan hukum primer dan bahan hukum sekunder seperti kamus hukum online diambil dalam media internet.

Metode pengumpulan data berupa bahan hukum primer, bahan hukum sekunder, dan bahan hukum tersier. Contoh pengumpulan datanya yakni studi kepustakaan, seperti buku-buku yang ditulis oleh para ahli hukum khususnya hukum pewarisan, hukum jaminan dan hukum kepailitan, hukum waris Islam. Bahan hukum lainya seperti peraturan perundang-undangan, Putusan Pengadilan Niaga, Putusan Kasasi Mahkamah Agung dan Putusan Peninjauan Kembali Mahkamah Agung, Yurisprudensi Putusan Mahkamah Agung. Teknik analisis data mengggunakan pendekatan analisis kualitatif untuk mencari jawaban dan mendapatkan kesimpulan serta dapat menguraikan dan memecahkan masalah yang diteliti.

\section{Hasil Penelitian dan Pembahasan}

\section{Kewajiban Ahli terhadap Utang Pewaris Berdasarkan Hukum Islam}

Menurut Ahmad Azhar Basyir, kewarisan menurut hukum Islam adalah proses pemindahan harta peninggalan seseorang yang telah meninggal, baik yang berupa benda yang wujud maupun yang berupa hak kebendaan, kepada keluarganya yang dinyatakan berhak menurut hukum. ${ }^{7}$ Menurut Amir Syarifuddin, hukum kewarisan Islam itu dapat diartikan seperangkat peraturan tertulis berdasarkan wahyu Allah dan sunnah Nabi tentang hal ihwal peralihan

${ }^{7}$ Ahmad Azhar Basyir, Hukum Waris Islam, UII Press, Yogyakarta, 2004, hlm. 132. 
harta atau berwujud harta dari yang telah mati kepada yang masih hidup, yang diakui dan diyakini berlaku dan mengikat untuk semua yang beragama Islam. ${ }^{8}$

Ketentuan Kompilasi Hukum Islam Buku II, BAB I tentang Ketentuan umum telah memisahkan konsep antara harta peninggalan dan harta warisan. Harta peninggalan adalah harta yang ditinggalkan oleh pewaris baik yang berupa harta benda yang menjadi miliknya maupun hak-haknya. Sedangkan yang dimaksud mengenai harta warisan adalah harta bawaan ditambah bagian dari harta bersama setelah digunakan untuk keperluan pewaris selama sakit sampai meninggalnya, biaya pengurusan jenazah (tajhiz), pembayaran utang dan pemberian untuk kerabat. ${ }^{9}$

Ketentuan positif dalam hukum kewarisan Islam selalu diberi penjelasan bahwa ahli waris baru dapat menerima harta warisan setelah dikurang dengan pembayaran utang dan wasiat. Dengan demikian, dapatlah disimpulkan bahwa hukum kewarisan Islam menuntut adanya pelunasan segala utang dan wasiat si pewaris sebelum harta warisan dibagikan. Para ahli waris tidak diwajibkan untuk menutupi kekurangan yang timbul karena tidak mencukupi harta peninggalan bagi pelunasan utang pewaris dengan kekayaan sejumlah harta peninggalan.

Konsep pewarisan hukum Islam mengenai tanggung jawab bagi ahli waris terhadap utang pewaris sebagaimana pendapat Abu Humaid Arif Syarifuddin, yang berpendapat bahwa:10

Demikianlah seharusnya setiap muslim mencontoh Rasulullah SAW. Sehingga, utang yang menjadi tanggungan diri seorang muslim. Hendaknya segera ditunaikan bila telah memiliki harta yang dapat untuk melunasinya, tidak mengulur-ulurnya, karena hal itu termasuk bentuk kezhaliman. Utang ini tetap akan menjadi tanggungannya, sampai ia mati sekalipun. Jika belum dilunasi, maka ruhnya akan tergantung sampai terlunasi Penguluran (utang) oleh utangnya

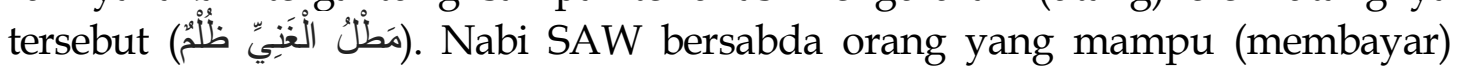
adalah kezhaliman). Beliau juga bersabda Jiwa (ruh) seorang mukmin tergantung

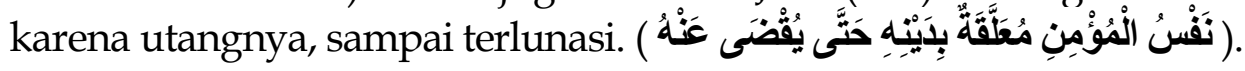

Berdasarkan pendapat tersebut, maka sebelum ahli waris menikmati haknya untuk mendapatkan harta warisan dari pewaris maka ahli waris terlebih dahulu berkewajiban untuk melunasi segala utang pewaris. Pelunasan utang merupakan

${ }^{8}$ Amir Syarifuddin, Hukum Kewarisan Islam, Prenada Media, Jakarta, 2004, hlm. 6.

9 Ilyas, “Tanggung Jawab Ahli Waris Terhadap Utang Pewaris Berdasarkan Hukum Islam”, Kanun Jurnal Ilmu Hukum, Vol. 13 No. 55, Desember 2011, hlm. 135-136.

${ }^{10}$ Abu Humaid Arif Syarifuddin, Al-Manhaj, Yayasan Lajnah Istiqamah, Surakarta, 2005, hlm. 5. 
kewajiban yang harus dilunasi oleh setiap orang yang memeluk agama Islam. Salaman bin Al- Akwa ra menuturkan Nabi SAW pernah tidak mau menyalati jenazah seseorang, karena si mayit tersebut masih memiliki tanggungan utang: ${ }^{11}$

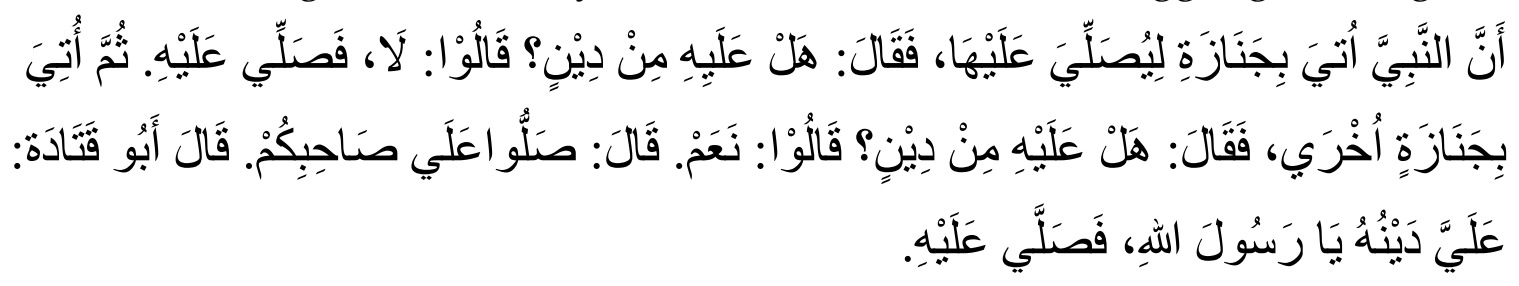

Artinya:

Bahwasanya, pernah dihadapkan kepada Nabi SAW seorang jenazah untuk beliau shalati. Lalu beliau bertanya, "Apakah dia punya utang?" Mereka menjawab, "Tidak", maka beliau pun menyalatinya. Kemudian didatangkan kepada beliau jenazah yang lain, lalu beliau bertanya, "Apakah dia punya utang?", Mereka menjawab, "Ya" maka beliau berkata, "Shalatilah teman kalian ini oleh kalian”. Abu Qatadah berkata, “Wahai Rasulullah. Saya yang akan melunasi utangnya", maka beliau pun mau menyalatinya".

Seseorang meninggal di antara hak yang harus ditunaikan sebelum dilakukan pembagian warisan dari harta yang ditinggalkan untuk para ahli warisnya ialah melunasi utang-utang si mayit bila ia meninggalkan utang, baik utang yang terkait dengan hak Allah maupun hak manusia. Muhammad Daud Ali memberikan pendapat terhadap harta peninggalan ahli waris dan pertanggungjawaban bagi diri ahli waris, yakni sebagai berikut: ${ }^{12}$ Apabila seseorang meninggal dunia dengan meninggalkan utang, maka utang orang yang meninggal tersebut menjadi tanggung jawab ahli waris yang harus dibayar oleh para ahli warisnya. Akan tetapi, apabila harta warisan tidak mencukupi untuk pelunasan utang-utang tersebut, maka tidak ada kewajiban bagi ahli waris untuk membayarnya.

Mengenai hak dan kewajiban bagi ahli waris mempunyai hak dan kewajiban terhadap harta peninggalan yang ia terima. Hak ahli waris adalah menerima harta warisan yang menjadi bagiannya. Sebaliknya ahli waris pun mempunyai beberapa kewajiban sebagai ahli waris. Kewajiban yang dimaksud di antaranya mengurus biaya perawatan jenazah, segala utang pewaris dan sebagainya. Dengan kata lain, sebelum dilaksanakan pembagian warisan, terlebih dahulu harus diselesaikan beberapa hak

${ }^{11}$ Nuzha, "Wasiat \& Utang Dalam Warisan”, Jurnal Al-Qadāu, Vol. 2 No. 2 Desember 2015, hlm. 170-171.

12 Muhammad Daud Ali, Hukum Dan Peradilan Agama, PT. Raja Grafindo Persada, Jakarta, 1997, hlm. 126. 
yang ada sangkut pautnya dengan harta peninggalan itu. Hak-hak yang harus diselesaikan dan dibayar, adalah: ${ }^{13}$ a. Zakat, b. Belanja; c. utang, d. Wasiat.

Menurut kalangan Hanabilah, utang-utang erat kaitanya dengan harta waris dimana penunaianya dilaksanakan setelah pembiayaan untuk si mayat lebih didahulukan ketimbang utang-utang tadi, sebagaimana seorang yang pailit mendahulukan menafkahi dirinya atas kreditornya dan pakaian orang yang pailit lebih diutamakan daripada pelunasan utangnya. Mengenai mayit lebih didahulukan atas pelunasan utang-utangnya, disebabkan menutupi auratnya di masa dia hidup merupakan suatu kewajiban, setelah dia meninggal dunia. ${ }^{14}$

Ketentuan Pasal 171 ayat e Kompilasi Hukum Islam disebutkan bahwa yang dimaksud dengan harta warisan adalah harta bawaan ditambah bagian dari harta bersama setelah digunakan untuk keperluan pewaris (orang yang meninggal) selama sakit sampai meninggalnya, biaya pengurusan jenazah (tahjiz), pembayaran utang, dan pemberian untuk kerabat. ${ }^{15}$ Sebelum harta peninggalan dibagikan kepada ahli waris, terlebih dahulu harus dikeluarkan hak-hak yang berhubungan dengan harta peninggalan si mayat, terutama utang yang ditinggalkan oleh pewaris. Utang merupakan tanggungan yang harus dilunasi dalam waktu tetentu (yang disepakati) sebagai akibat dari imbalan yang telah diterima oleh orang yang utang. Apabila seseorang yang meninggalkan utang pada orang lain yang belum dibayar, maka sudah seharusnya utang tersebut dilunasi dari harta peninggalannya sebelum harta itu dibagikan kepada ahli waris. ${ }^{16}$ Jumhur ulama mengklasifikasikan utang menjadi 2 macam, yaitu:17 1) Utang kepada sesama manusia, utang kepada sesama manusia ditinjau dari segi teknis pelaksanaannya dibagi menjadi dua. Pertama, utang yang berhubungan dengan wujud harta. Kedua, utang yang tidak bersangkutan dengan wujud harta; 2) Utang kepada Allah SWT (dayn Allah), utang kepada Allah maksudnya adalah semua utang yang berkaitan dengan hak Allah SWT seperti utang nazar, utang zakat, kafarah dan lain-lain. ${ }^{18}$

\footnotetext{
${ }^{13}$ M. Ali Hasan, Hukum Warisan dalam Islam, Bulan Bintang, Jakarta, 1979, hlm. 10.

14 Addys Aldizar dan Fathurrahman, Abli Waris, Senayan Abadi Publishing, Jakarta, 2004, hlm. 71

${ }^{15}$ Amin Husein Nasution, Hukum Kewarisan, Rajawali Pers, Medan, 2012, hlm. 57.

16 Ahmad Rofiq, Fiqh Mawaris, PT. Raja Grafindo, Jakarta, 1995, hlm. 38.

${ }^{17}$ Ibid., hlm. 39.

${ }^{18}$ Muhammad Ali Al Sabuni, Al-Mawaris Fi Al-Syari'atil Islamiyah, Trigenda Karya, Bandung, 1995, hlm. 42.
} 
Persoalanya ialah apabila utang-utang yang ada kepada Allah dan sesama manusia lebih banyak jumlahnya ketimbang harta peninggalan lalu bagaimana solusinya? Para utama fiqih berpendapat mengenai utang harus didahulukan di antara dua bentuk utang. Perbedaan pendapat itu bisa dilihat di bawah ini: ${ }^{19}$

a) "Kalangan Hanafiyyah dan Malikiyyah berpendapat bahwa utang sesama manusia pelunasannya lebih didahulukan sebab, manusia sangat memerlukan untuk dilunasi piutangnya, sedangkan Allah SWT adalah zat yang sudah cukup, sehingga tidak perlu pelunasan kepadanya.

b) Kalangan Syafi'iyyah berpendapat, menurut pendapat yang sahih, yang harus didahulukan adalah utang kepada Allah ketimbang hak kepada sesama manusia, sesuai dengan sabda Nabi Saw, "Utang kepada Allah lebih utama dilunasi." Dalam hadits yang lain beliau bersabda "Lunasilah hak Allah, karena dia lebih berhak untuk dilunasi.

c) Kalangan Hambaliyyah berpendapat bahwa kedudukan pelunasan utang terhadap Allah sama dengan pelunasan utang terhadap manusia. Maksudnya, harta waris dibagi menurut perbandingan kedua macam utang tersebut, seperti pembagian harta orang pailit semasa hidupnya."

Menurut Mahmud Syaltut Islam menentukan bahwa harta peninggalan yang akan dibagikan antara ahli waris menurut prinsip di atas, ialah sisa kekayaan sesudah pembayaran utang dari orang yang meninggal. ${ }^{20}$ Sebagaimana yang dijelaskan juga dalam Pasal 175 Kompilasi Hukum Islam:

1) "Kewajiban ahli waris terhadap pewaris adalah:

a. Mengurus dan menyelesaikan sampai pemakaman jenazah selesai.

b. Menyelesaikan baik utang-utang berupa pengobatan, perawatan, termasuk kewajiban pewaris maupun menagih piutang.

2) Tanggung jawab ahli waris terhadap utang atau kewajiban pewaris hanya terbatas pada jumlah atau nilai harta peninggalannya."

\section{Pertanggungjawaban Ahli Waris Sebagai Debitor Pailit terhadap Perjanjian Jaminan Perorangan yang Dibuat Pewaris Ditinjau dari Aspek Hukum Islam}

Hak jaminan perorangan adalah hak yang memberikan kepada kreditur suatu kedudukan yang lebih baik, karena adanya lebih dari seorang debitur yang dapat ditagih. Kata "lebih baik" di sini adalah lebih baik daripada kreditur yang tidak mempunyai hak jaminan (khusus) atau lebih baik dari jaminan umum. Adanya lebih dari seorang debitur, bisa karena ada debitur serta tanggung-menanggung

\footnotetext{
19 Addys Aldizar dan Fathurrahman, Op. Cit., hlm 70.

${ }^{20}$ Syekh Mahmud Syaltut, Akidah dan Syari'ah Islam, PT Bumi Aksara, Jakarta, 1994, hlm. 246.
} 
atau karena adanya orang pihak ketiga yang mengikatkan dirinya sebagai borg. Jaminan perorangan ini dapat berupa penjamin utang jaminan perusahaan, perikatan tanggung-menanggung, dan garansi bank.

Adanya perjanjian jaminan perorangan antara kreditor dengan penjamin utang, maka lahirlah akibat hukum berupa hak dan kewajiban antara penjamin dan kreditor. Kewajiban dari penjamin adalah untuk memenuhi prestasi atau melunasi utang yang ditanggungkanya demi kepentingan kreditor, namun dalam hubungan hukum tersebut ada hak- hak penanggung yakni: a. Hak untuk menutup terlebih dahulu harta debitor disita (Pasal 1831 BW) b. Hak untuk membagi utang (Pasal 1836 BW) c. Hak untuk mengajukan tangkisan gugatan (Pasal 1849, 1850 BW) d. Hak untuk diberhentikan dari penanggung (Pasal 1848 BW). ${ }^{21}$

Gunawan Widjaja dan Kartini Muljadi mengatakan Penjamin/guarantor memiliki hak istimewa. Hak istimewa penjamin ini membawa akibat hukum bahwa penjamin tidak diwajibkan untuk melunasi kewajiban debitor kepada kreditor sebelum debitor cidera janji penjualan harta kekayaan debitor tidak mencukupi untuk memenuhi kewajiban debitor kepada kreditor. Dalam hal yang demikian berarti penjamin hanya akan melunasi sisa kewajiban debitor yang belum dipenuhinya kepada kreditor." 22 Sunarmi mengatakan penjamin/guarantor tidak dapat menuntut supaya harta debitor disita terlebih dahulu dan dijual untuk melunasi utangnya jika penjamin telah melepaskan hak istimewanya yang diatur dalam Pasal 1831 BW. ${ }^{23}$

Penjamin dalam kasus kepailitan adalah debitor dari kewajiban untuk menjamin pembayaran oleh debitor utama. ${ }^{24}$ Kedudukan antara debitor utama dengan penjamin atau personal guarantee atau borgtocht adalah sama-sama seorang debitor. Penjamin berkewajiban melunasi utang debitor utama kepada kreditornya

${ }^{21}$ Nurman Hidayat, “Tanggung Jawab Penanggung Dalam Perjanjian Kredit”, Jurnal Ilmu Hukum Legal Opinion, Vol. 2 No. 4, Juli 2014, hlm. 5.

${ }^{22}$ Kartini Muljadi dan Gunawan Widjaja, Seri Hukum Harta Kekayaan, Hak Tanggungan, Kencana, Jakarta, 2005, hlm. 24-25.

23 Sunarmi, Hukum Kepailitan, USU Press, Medan, 2009, hlm. 197.

24 Imran Nating, Tanggung Jawab Kurator dalam Pengurusan dan Pemberesan Harta Pailit, Raja Grafindo Persada, Jakarta, 2004, hlm. 33 . 
jika debitor utama tidak membayar utang yang jatuh waktu sehingga dikatakan penjamin sebagai debitor yang dapat dinyatakan pailit. ${ }^{25}$

Ketentuan penjamin dapat diajukan permohonan pailit ketika penjamin telah melepaskan hak-hak istimewanya, terutama untuk penjamin yang telah menyatakan dirinya bertanggung jawab renteng dengan debitor utama. Kreditor dapat langsung mengajukan permohonan pailit dengan pengajuan sebagai berikut: ${ }^{26}$ a. surat perjanjian kredit, b. surat perjanjian penanggungan guarantor telah melepaskan hak istemewa dan menyatakan bertanggung jawab renteng dengan debitor utama, c. guarantor termohon pailit mempunyai utang pada kreditor lain, d. salah satu utang tersebut telah jatuh waktu dan dapat ditagih.

Penjamin yang telah meninggal dunia setelah melakukan perjanjian kredit dengan kreditor maka segala tanggung jawab terhadap perikatan diahlikan kepada ahli warisnya sebagaimana Pasal 1826 BW. Mengenai pertanggungjawaban terhadap kewajiban ahli waris merupakan asas yang tercantum di dalam BW yakni asas saisine. Ahli waris segera menggantikan hak dan kewajiban dari pewaris tanpa memerlukan suatu perbuatan tertentu. Beralihnya segala hak dan kewajiban pewaris secara sendiri atau otomatis, tanpa dibutuhkan tindakan tertentu dari ahli waris tersebut yang disebut dengan hak saisine. ${ }^{27}$

Ketentuan mengenai asas saisine terdapat dalam Pasal 833 BW yang menyebutkan bahwa sekalian ahli waris demi hukum memperoleh hak milik atas semua barang, semua hak dan semua piutang dari yang meninggal. Dengan demikian, ahli waris mempunyai tanggung jawab terhadap boedel waris yang diterimanya untuk menanggung segala utang-utang pewaris. Ketentuan yang diatur di dalam hukum perdata barat ahli waris dapat menentukan sikap dan dapat membuat pilihan terhadap warisan yang terbuka tersebut. Pewaris diberikan waktu untuk berpikir dalam menentukan sikapnya atas pewarisan yaitu dengan menerima harta warisan secara penuh, menerima warisan bersyarat, atau menolak harta

\footnotetext{
25 Luky Pangastuti, "Pertanggungjawaban Pihak Personal Guarantee Yang Dinyatakan Pailit", Jurnal Repertorium, Vol. II No. 2, Juli-Desember 2015, hlm. 152.

${ }^{26}$ Ibid., hlm. 151.

27 Oemar Moechthar, "Kedudukan Negara Sebagai Pengelola Warisan Atas Harta Peninggalan Tak Terurus Menurut Sistem Waris Burgerlijk Wetboek", Yuridika, Vol. 32 No. 2, Mei 2017, hlm. 291.
} 
warisan. ${ }^{28}$ Ahli waris menerima secara penuh maka tanggung jawab terhadap utang dibebankan pada dirinya termasuk sebagai penjamin utang peninggalan pewaris.

Tanggung jawab ahli waris dari pewaris pemegang jaminan perorangan ini secara normatif sudah jelas aturannya jika mengacu pada ketentuan Pasal 1826 BW. Sebab muatan Pasal 1826 BW ini pada intinya menentukan bahwa perikatanperikatan penanggungan berpindah kepada para ahli waris. Pada pengaturanya jika pemegang jaminan perorangan meninggal dunia, maka secara hukum hak dan kewajibannya beralih kepada ahli waris.

Penerapan Pasal 1826 BW dalam kasus kepailitan yang melibatkan ahli waris secara serta merta tanpa mempertimbangkan aspek kemanfaatan dan aspek keadilan ternyata menimbulkan persoalan hukum baru. Persoalan hukum baru yang timbul dari penerapan Pasal 1826 BW dalam perkara kepailitan maka harta pribadi ahli waris akan ikut dilakukan sitaan umum. Harta kekayaan ahli waris tidak sebatas harta warisan tetapi juga harta pribadi ahli waris sebagaimana Pasal 1 angka (1) UU Kepailitan dan PKPU juncto Pasal 21 UU Kepailitan dan PKPU. Jerry Hoff yang dikutip oleh Purbandari ${ }^{29}$ mengatakan apabila si debitor tidak membayar utangnya walaupun telah ada putusan pengadilan yang menghukum supaya melunasi utangnya atau karena tidak mampu membayar seluruh utangnya, seluruh harta bendanya disita untuk dijual dan hasil penjualan itu dibagikan antara semua kreditor, menurut besar kecilnya piutang masing-masing kreditor, kecuali apabila di antara kreditor ada alasan yang sah untuk didahulukan.

Majelis hakim Pengadilan Niaga Pengadilan No. 02/Pdt.Sus Pailit/2014/PN Niaga Mks, mengabulkan permohonan pailit pemohon pailit kreditor Greenfich Premier Fund. Pertimbangan majelis hakim pengadilan mengacu pada Pasal 1826 BW terkait pertanggung jawaban ahli waris yang dijadikan debitor pailit. Akibat hukum dari Putusan Pengadilan No. 02/Pdt.Sus Pailit/2014/PN Niaga Mks, maka status a quo beralih dari ahli waris menjadi debitor pailit dan ahli waris alm. AS dan alm. GS, serta Debitor PT. Henrison Iriana bertanggung jawab renteng terhadap segala piutang kreditor pemohon pailit dan kreditor-kreditor lainnya. Berdasarkan

${ }^{28}$ Muchtar A. H. Labetubun dan Sabri Fataruba, "Peralihan Hak Cipta Kepada Ahli Waris Menurut Hukum Perdata", Jurnal Sasi, Vol. 22 No. 2, Juli-Desember 2016, hlm. 9.

${ }^{29}$ Purbandari, "Tanggung Jawab Perseroan Terbatas Yang Dinyatakan Pailit", Jurnal Widya Yustisia, Vol. 1 No. 1, Mei 2014, hlm. 33. 
ketentuan Pasal 21 UU Kepailitan dan PKPU berbunyi: Kepailitan meliputi seluruh kekayaan debitor pada saat putusan pernyataan pailit diucapkan serta segala sesuatu yang diperoleh selama kepailitan. Selanjutnnya di Pasal 24 ayat (1) dan (2) UU Kepailitan dan PKPU mengakibatkan debitor kehilangan haknya sejak diputus pailit dihitung pukul 00.00 waktu setempat.

Sebelum pernyataan pailit hak-hak debitor untuk melakukan semua tindakan hukum berkenaan dengan kekayaan harus dihormati tentunya dengan memperhatikan hak kontraktual serta kewajiban debitor menurut perundangundangan. Titik Tejaningsih menyatakan bahwa: ${ }^{30}$

a. Semenjak pengadilan mengucapkan putusan kepailitan dalam sidang yang terbuka untuk umum terhadap debitor, maka hak dan kewajiban si pailit beralih kepada kurator untuk mengurus dan menguasai boedel-nya,

b. Kepailitan semata-mata hanya mengenai harta pailit dan tidak mengenai diri pribadi debitor pailit,

c. Debitor pailit demi hukum kehilangan hak untuk mengurus dan menguasai kekayaannya yang termasuk harta pailit, sejak hari tanggal putusan pailit diucapkan,

d. Segala perikatan debitor yang timbul sesudah putusan pernyataan pailit diucapkan tidak dapat dibayar dari harta pailit kecuali jika menguntungkan harta pailit,

e. Harta pailit diurus dan dikuasai kurator untuk kepentingan semua para kreditor dan debitor dan hakim pengawas memimpin dan mengawasi pelaksanaan jalanya kepailitan.

Pendapat di atas tersebut juga menegaskan terhadap upaya hukum yang diajukan oleh Ahli Waris Alm. AS melalui permohonan Kasasi No. 19 K/Pdt. SusPailit/2015 yang menguatkan Putusan Pengadilan Niaga No. 02/Pdt.Sus Pailit/2014/Pn Niaga Mks, dan upaya hukum terakhir melalui Putusan Peninjauan Kembali MA No. 125 PK/Pdt.Sus/Pailit/2015 yang mengabulkan permohonan ahli waris AS dan GS. Pertimbangan majelis hakim Peninjauan Kembali memberikan pendapatnya yang menyatakan sebagai berikut:

“Tidak diperoleh bukti yang cukup bahkan tidak ada bukti sama sekali kalau cessie tersebut telah diberitahukan kepada berutang (ahli waris Alm. AS dan GS) sebagaimana diatur di dalam Pasal 613 BW. Sehingga tidak dapat dibuktikan secara sederhana pembuktian kepailitan tersebut sebagaimana Pasal 8 ayat (4) UU Kepailitan dan PKPU."

30 Titik Tejaningsih, Perlindungan Hukum Terbadap Kreditor Separatis Dalam Pengurusan dan Pemberesan Harta Pailit, FH UII Press, Yogyakarta, 2016, hlm. 65 - 66. 
Berdasarkan pertimbangan hakim tersebut, majelis hakim tidak mempersoalkan mengenai tanggung jawab ahli waris sebagai penjamin perusahaan yang pailit namun hanya mengenai pembuktian secara formil yang diajukan di pengadilan. Kendatinya Putusan Peninjauan Kembali tetap tidak membatalkan segala tindakan kurator yang sudah dijalankanya, sehingga harta pribadi ahli waris yang sudah disita dan dilelang tidak dapat kembali jatuh ke tanganya. Ketentuan ini dipertegas dalam Pasal 16 UU Kepailitan dan PKPU yang menjelaskan sebagai berikut:

1) "Kurator berwenang melaksanakan tugas pengurusan dan/atau pemberesan atas harta pailit sejak tanggal putusan pailit diucapkan meskipun terhadap putusan tersebut diajukan kasasi atau peninjauan kembali.

2) Dalam hal putusan pernyataan pailit dibatalkan sebagai akibat adanya kasasi atau peninjauan kembali, segala perbuatan yang telah dilakukan oleh Kurator sebelum atau pada tanggal Kurator menerima pemberitahuan tentang putusan pembatalan sebagaimana dimaksud dalam Pasal 17 tetap sah dan mengikat Debitor."

Pengaturan hukum kepailitan mengenai kewajiban ahli waris sebagai debitor pailit dari penjamin perusahaan yang pailit, jika ditinjau dari aspek hukum kewarisan Islam sangat berbeda dan tidak relevan. Pengaturan hukum Islam menyatakan jika seseorang meninggal dunia, maka pewaris meninggalkan harta dan ahli waris. Oleh karena itu, harta warisan tidak mutlak menjadi hak ahli waris, sebab dalam harta warisan itu ada kewajiban yang harus dikeluarkan terlebih dahulu sebelum harta tersebut dibagikan kepada para ahli warisnya. Dari pemikiran ini diketahui bahwa pelunasan terhadap utang pewaris merupakan suatu hal yang wajib dipenuhi oleh ahli waris sebelum harta itu dibagikan. Mengenai tanggung jawab ahli waris ini dalam Pasal 175 ayat (2) Kompilasi Hukum Islam (KHI) ditentukan bahwa pada prinsipnya tanggung jawab ahli waris terhadap utang atau kewajiban pewaris hanya terbatas pada jumlah atau nilai harta peninggalannya. Ketentuan Pasal 175 Kompilasi Hukum Islam selengkapnya berbunyi sebagai berikut:

1) "Kewajiban ahli waris terhadap pewaris adalah:

a. mengurus dan menyelesaikan sampai pemakaman jenazah selesai;

b. menyelesaikan baik utang-utang berupa pengobatan, perawatan, termasuk kewajiban pewaris maupun penagih piutang;

c. menyelesaikan wasiat pewaris; 
d. membagi harta warisan di antara ahli waris yang berhak.

2) Tanggung jawab ahli waris terhadap utang atau kewajiban pewaris hanya terbatas pada jumlah atau nilai harta peninggalannya."

Muatan Pasal 175 KHI tersebut mengandung makna bahwa ahli waris bertanggung jawab untuk menyelesaikan baik utang-utang berupa pengobatan, perawatan, termasuk kewajiban pewaris maupun penagih piutang. Namun demikian tanggung jawab ahli waris ini bersifat terbatas. Tanggung jawab terbatas ini adalah tanggung jawab ahli waris terhadap utang atau kewajiban pewaris hanya terbatas pada jumlah atau nilai harta peninggalannya. Dengan kata lain, dalam hukum Islam, tanggung jawab ahli waris terhadap utang pewaris hanya terbatas pada jumlah harta peninggalannya, dan tidak boleh menimbulkan kerugian bagi ahli waris itu sendiri. Jadi pembayaran atas utang pewaris hanya dapat diambilkan dari harta warisan. Ahli waris tidak dapat dituntut atau dipaksa untuk membayar atau melunasi seluruh utang pewaris, tetapi apabila utang pewaris sudah dilunasi, maka sisa tersebut menjadi hak ahli waris itu sendiri.

Penerapan hukum yang diatur di dalam Pasal 175 ayat (2) UU KHI telah dijadikan pertimbangan bagi hakim dalam memutus perkara perdata. Mahkamah Agung telah mengeluarkan Putusan yang merupakan kaidah hukum (yurisprudensi) pada perkara Putusan No. 3574 K/Pdt./200031. Putusan Hakim ini awalnya merupakan gugatan wanprestasi yang diajukan di Pengadilan Negeri dengan menggunakan dasar ketentuan hukum yang berkiblat pada hukum barat sebagaimana Pasal 1243 BW ${ }^{32}$. Pada perkara tersebut, pemohon meminta untuk melakukan sita jaminan (conservatoir beslag) terhadap isteri pewaris, namun memberikan pertimbangan hukum menggunakan Pasal 175 ayat (2) KHI yang berkiblat menggunakan hukum Islam. Adapun pertimbangan Majelis Hakim kasasi menyatakan bahwa mengenai tanggungjawab ahli waris terhadap utang pewaris hanya terbatas pada jumlah atau nilai harta peninggalan." Dalam hubungannya dengan keterangan di atas, maka yang menjadi persoalan adalah

${ }^{31}$ Lihat Yurisprudensi Mahkamah Agung No. 3574 K/Pdt./2000.

32 Pasal 1243 BW yang berbunyi sebagai berikut, "Penggantian biaya, kerugian dan bunga karena tak dipenuhinya suatu perikatan mulai diwajibkan, bila debitur, walaupun telah dinyatakan Ialai, tetap lalai untuk memenuhi perikatan itu, atau jika sesuatu yang harus diberikan atau dilakukannya hanya dapat diberikan atau dilakukannya dalam waktu yang melampaui waktu yang telah ditentukan”. 
bagaimana hak-hak ahli waris pada saat harta pewarisan terbuka dalam KUH Perdata ditinjau dari hukum Islam.

Setiap ketentuan positif dalam hukum kewarisan Islam selalu diberi penjelasan bahwa ahli waris baru dapat menerima harta warisan setelah dikurang dengan pembayaran utang dan wasiat. Dengan demikian dapatlah disimpulkan bahwa hukum kewarisan Islam menuntut adanya pelunasan segala utang dan wasiat si pewaris sebelum harta warisan dibagikan. Para ahli waris tidak diwajibkan untuk menutupi kekurangan yang timbul karena tidak mencukupi harta peninggalan bagi pelunasan utang pewaris dengan kekayaan sejumlah harta peninggalan.

Untuk memberikan perlindungan hukum terhadap harta ahli waris bagi orang Islam dari pewaris jaminan perorangan yang dipailitkan. Maka perlu adanya revisi di dalam UU Kepailitan dan PKPU mengenai harta ahli waris yang dibebankan untuk pelunasan utang kreditor, dibatasi atau dipisahkan antara harta boedel waris dan harta pribadi. Rumusan Pasal penjelasan Pasal 1 angka (1) UU Kepailitan dan PKPU juncto Pasal 21 UU Kepailitan dan PKPU dikecualikan terhadap harta ahli waris yang beragama Islam agar relevan dengan Pasal 175 ayat (2) Kompilasi hukum Islam yang memisahkan harta kekayaan orang meninggal dengan harta ahli warisnya. Kurator membereskan harta pailit tidak melakukan eksekusi terhadap ahli waris yang menggunakan pengaturan hukumnya menggunakan waris Islam yang diatur di dalam pengaturan Kompilasi Hukum Islam.

Ketentuan dipisahkanya harta ahli waris pribadi dengan boedel waris yang diterima ahli waris juga normanya sudah diatur di dalam Pasal 209 UU Kepailitan dan PKPU namun hanya untuk pengajuan permohonan kepailitan terhadap harta peninggalan yang dipailitkan. Bagi subyek atau dalam hal ini ahli waris yang dijadikan debitor pailit maka berlaku sitaan umum terhadap seluruh asetnya untuk dijadikan boedel pailit oleh kurator.

\section{Penutup}

Hasil penelitian ini menyimpulkan bahwa: pertama, ahli waris dari pewaris pemegang jaminan perorangan jika ditinjau dalam aspek hukum waris Islam, maka ahli waris mempunyai kewajiban untuk membayar utang dari pewarisnya. Pengaturan tanggung jawab ahli waris dalam Pasal 175 ayat (2) Kompilasi Hukum 
Islam menyatakan pada prinsipnya ahli waris hanya bertanggung jawab terhadap utang pewaris yang ditentukan sebatas pada jumlah atau nilai harta peninggalannya.

Kedua, akibat hukum bagi ahli waris pemegang jaminan perorangan dipailitkan maka tidak dapat dilakukan sitaan umum terhadap segala harta kekayaan milik ahli waris untuk melunasi seluruh utang kreditornya. Artinya, tanggungjawab ahli waris bersifat terbatas. Ahli waris hanya bertanggungjawab melunasi utang sebatas dari harta peninggalan pewaris dan tidak diwajibkan untuk menutupi kekurangan yang timbul karena harta peninggalan tidak cukup bagi pelunasan utang.

Peneliti menyarankan terkait perlindungan hukum terhadap harta ahli waris bagi orang Islam maka rumusan Pasal ataupun penjelasan Pasal 1 angka (1) UU Kepailitan dan PKPU juncto Pasal 21 UU Kepailitan dan PKPU dikecualikan terhadap harta ahli waris yang beragama Islam agar relevan dengan Pasal 175 ayat (2) Kompilasi hukum Islam yang memisahkan harta kekayaan orang meninggal dengan harta ahli warisnya sebatas jumlah harta yang ditinggalkanya. Sehingga kurator dalam membereskan harta pailit tidak melakukan eksekusi terhadap ahli waris yang menggunakan pengaturan hukumnya menggunakan waris Islam.

\section{Daftar Pustaka}

\section{Buku:}

Aldizar, Addys, dan Fathurrahman, Ahli Waris, Senayan Abadi Publishing, Jakarta, 2004.

Al Sabuni, Muhammad Ali, Al-Mawaris Fi Al-Syari'atil Islamiyah, Trigenda Karya, Bandung, 1995.

Ali, Muhammad Daud, Hukum Dan Peradilan Agama, PT, Raja Grafindo Persada, Jakarta, 1997.

Basyir, Ahmad Azhar, Hukum Waris Islam, UII Press, Yogyakarta, 2004.

Hasan, M. Ali, Hukum Warisan dalam Islam, Bulan Bintang, Jakarta, 1979.

Hermansyah, Hukum Perbankan Nasional Indonesia, Prenada Media Group, Jakarta, 2014.

Muljadi, Kartini dan Widjaja, Gunawan, Seri Hukum Harta Kekayaan: Hak Tanggungan, Kencana, Jakarta, 2005.

Nasution, Amin Husein, Hukum Kewarisan, Rajawali Pers, Medan, 2012. 
Nating, Imran, Tanggung Jawab Kurator dalam Pengurusan dan Pemberesan Harta Pailit, Raja Grafindo Persada, Jakarta, 2004.

Rofiq, Ahmad, Fiqh Mawaris, PT. Raja Grafindo, Jakarta, 1995.

Subekti, Ringkasan Tentang Hukum Keluarga dan Hukum Waris, Intermesa, Jakarta, 2005.

Sunarmi, Hukum Kepailitan, USU Press, Medan, 2009.

Syaltut, Mahmud Syekh, Akidah dan Syari'ah Islam, PT Bumi Aksara, Jakarta, 1994.

Syarifuddin, Amin, Hukum Kewarisan Islam, Prenada Media, Jakarta, 2004.

Tejaningsih, Titik, Perlindungan Hukum Terhadap Kreditor Separatis Dalam Pengurusan dan Pemberesan Harta Pailit, FH UII Press, Yogyakarta, 2016.

Usman dan Somawinata, Fiqih Maswaris Hukum Kewarisan Islam, Gaya Media Pratama, Jakarta, 1997.

\section{Jurnal}

Fauzi, Mohammad Yasir, "Legislasi Hukum Kewarisan Indonesia” dalam Jurnal Pengembangan Masyarakat Islam, Vol. 9 No. 2, Agustus, 2016.

Hidayat, Nurman, “Tanggung Jawab Penanggung Dalam Perjanjian Kredit” dalam Jurnal Ilmu Hukum Legal Opinion, Vol. 2 No. 4, Juli, 2014.

Ilyas, “Tanggung Jawab Ahli Waris Terhadap Utang Pewaris Berdasarkan Hukum Islam" dalam Kanun Jurnal Ilmu Hukum, Vol.13 No. 55, Desember, 2011.

Komari, "Dinamisasi dan Elastistas Hukum Kewarisan Islam" dalam Jurnal Hukum dan Peradilan, Vol. 1 No. 3, Nopember, 2012.

Labetubun, Muchtar A. H., Dan Sabri Fataruba, "Peralihan Hak Cipta Kepada Ahli Waris Menurut Hukum Perdata" dalam Jurnal Sasi, Vol. 22 No. 2, JuliDesember, 2016.

Luky Pangastuti, "Pertanggungjawaban Pihak Personal Guarantee Yang Dinyatakan Pailit" dalam Jurnal Repertorium, Vol. II No. 2, Juli-Desember, 2015.

Moechthar, Oemar, "Kedudukan Negara Sebagai Pengelola Warisan Atas Harta Peninggalan Tak Terurus Menurut Sistem Waris Burgerlijk Wetboek" dalam Yuridika, Vol. 32 No. 2, Mei, 2017.

Nuzha, "Wasiat \& Utang Dalam Warisan” dalam Jurnal Al-Qadāu, Vol. 2 No.2, Desember 2015.

Pradana, Yudha, "Kedudukan Ahli Waris Penanggung Perseroan Pada Perseroan Terbatas Yang Dipailitkan Secara Bersama-sama" dalam Diponegoro Law Journal, Vol. 5 No. 3, Juli, 2016.

Prasetyawati, Niken dan Tony Hanoraga, "Jaminan Kebendaan dan Jaminan Perorangan Sebagai Upaya Perlindungan Hukum Bagi Pemilik Piutang" dalam Jurnal Sosial Humaniora, Vol. 8 No. 1, Juni, 2015. 
Purbandari, "Tanggung Jawab Perseroan Terbatas Yang Dinyatakan Pailit" dalam Jurnal Widya Yustisia, Vol. 1 No. 1, Mei, 2014.

\section{Peraturan Perundangan}

Kitab Undang-Undang Hukum Perdata, Burgerlijk Wetboek voor Indonesie, Staatsblad Tahun 1847 Nomor 23.

Undang-Undang No. 37 Tahun 2004 Tentang Kepailitan dan Penundaan Kewajiban Pembayaran Utang, Lembaran Negara Republik Indonesia Tahun 2004 Nomor 131, Tambahan Negara Republik Indonesia Nomor 4443.

Undang-Undang No. 1 Tahun 1974 Tentang Perkawinan, Lembaran Negara Republik Indonesia Tahun 1974 Nomor 1, Tambahan Lembaran Negara Republik Indonesia Nomor 3019.

Instruksi Presiden RI No. 1 Tahun 1991 tentang Kompilasi Hukum Islam, Keputusan Menteri Agama No. 154 Tahun 1991, Tanggal 22 Juli.

\section{Putusan Pengadilan}

Putusan Pengadilan Niaga Makasar Nomor: 02/Pdt.Sus.Pailit/2014/PN Niaga Mks.

Putusan Kasasi Mahkamah Agung Nomor 19 K/Pdt.Sus-Pailit/2015.

Putusan Kasasi Mahkamah Agung Nomort 3574 K/Pdt./ 2000.

Putusan Peninjauan Kembali Mahkamah Agung Nomor 125 PK/Pdt.SusPailit/2015 Tahun 2016. 